\title{
The East Japan Great Earthquake and Three Cases of Near-Drowning with Tsunami Due to the Earthquake
}

\author{
Yoshihiro Inoue*, Yasuhisa Fujino, Makoto Onodera, Satoshi Kikuchi, Masayuki Sato, \\ Hisaho Sato, Hironobu Noda, Masahiro Kojika, Yasushi Suzuki, Shigeatu Endo \\ Department of Critical Care Medicine, School of Medicine, Iwate Medical University, Morioka-shi, Japan \\ Email: ${ }^{*}$ inoue@iwate-med.ac.jp
}

Received 10 June 2014; revised 10 July 2014; accepted 10 August 2014

Copyright (C) 2014 by authors and Scientific Research Publishing Inc. This work is licensed under the Creative Commons Attribution International License (CC BY). http://creativecommons.org/licenses/by/4.0/

c) (i) Open Access

\section{Abstract}

We encountered the Great East Japan Earthquake on March 11, 2011. The magnitude of the earthquake is 9.0 and it is one of the greatest from A.D. 1900 to now. The earthquake developed large tsunami and many people living on the pacific coast of east Japan died from lung disorder caused by near drowning with tsunami. We also encountered three cases of lung disorders caused by near drowning. All three were females, and two of them were old elderly. All segments of both lungs were involved in all the three patients, necessitating ICU admission and endotracheal intubation and mechanical ventilation. All three died within three weeks. In at least two cases, misswallowing of oil was suspected from the features noted at the time of the detection. Many bacteria were detected from the phlegm of two cases.

\section{Keywords}

\section{Tsunami, Drowning, Pneumonia}

\section{Introduction}

As a result of a massive magnitude-9.0 earthquake that struck eastern Japan at 2:46 pm on March 11, 2011, an unimaginable tsunami developed and wreaked devastating damage on the Pacific Coast region from Aomori Prefecture to Chiba Prefecture. The energy of the earthquake was enormous, approximately 45 times the energy of the Great Kanto Earthquake of 1923 and approximately 1450 times the energy of the Great Hanshin Earthquake of 1995, and it even ranked 4th in scale among the earthquakes that have occurred worldwide since 1900.

\footnotetext{
${ }^{*}$ Corresponding author.

How to cite this paper: Inoue, Y., Fujino, Y., Onodera, M., Kikuchi, S., Sato, M., Sato, H., Noda, H., Kojika, M., Suzuki, Y. and Endo, S. (2014) The East Japan Great Earthquake and Three Cases of Near-Drowning with Tsunami Due to the Earthquake. Open Journal of Clinical Diagnostics, 4, 145-151. http://dx.doi.org/10.4236/ojcd.2014.43023
} 
The total number of dead and missing as a result of the earthquake exceeded 20,000, and more than 300,000 disaster victims were living in evacuation shelters. Three people who had been engulfed by the tsunami and rescued were taken to a local hospital, but because they had lapsed into serious respiratory failure as a result of near drowning, on the day after the disaster they were transported by helicopter to our facility inland.

\section{Case 1}

An 87-year-old woman. Past medical history: Pacemaker implanted for sinus node dysfunction. History of the present illness: She was engulfed by the tsunami that occurred on March 11, and was rescued. She was taken to a local general hospital, but her respiratory function was severely impaired, and after endotracheal intubation she left by helicopter shortly after 8 am the following day, March 12, and arrived at our center at 9:38 am. Status praesens: Consciousness level JCS300 and GCS4 (E1VTM2). The blood examination findings are shown in Table 1. The results of thoracic CT in the outpatient department are shown in Figure 1. Hospital course: She was admitted to the ICU. She was placed on mechanical ventilation, and treated with injection of antibiotics (PIPC). But her respiratory function gradually deteriorated and blood pressure slowly dropped, and she died of respiratory dysfunction at 7:05 am on March 13. It was impossible to contact the patient's family, and her remains were placed in the hospital morgue. The following day, March 14, the family came to the hospital and removed her remains.

\section{Case 2}

An 86-year-old woman. Past medical history: Bilateral eye surgery for cataracts. History of the present illness: She was engulfed at home by the tsunami that occurred on March 11. The family returned home and discovered the patient in cardiopulmonary arrest. They performed cardiopulmonary resuscitation, and because the patient started breathing again, they took her to a local general hospital (her clothing smelled of kerosene). Because her respiratory function deteriorated, on March 12 she was brought to our center by helicopter and examined at 10:21. Status praesens: Consciousness level: JCS100 and GCS10 (E1V4M5). The blood examination findings are shown in Table 2, and the X-p chest X-ray taken in the next day of admission is shown in Figure 2. Endotracheal intubation was performed in the outpatient department, and the patient was admitted to the ICU. Hospital course: She was treated with injection of antibiotics (DRPM) and placed on mechanical ventilation, and $\mathrm{FiO}_{2}$ was started at 1.0. As her respiratory function improved, $\mathrm{FiO}_{2}$ was reduced to 0.45 , but her respiratory function deteriorated again on March 22, and she died of respiratory dysfunction in the early hours of March 30. Stenotrophomonas maltophilia was detected in a bacteriological examination of her sputum (March 17).

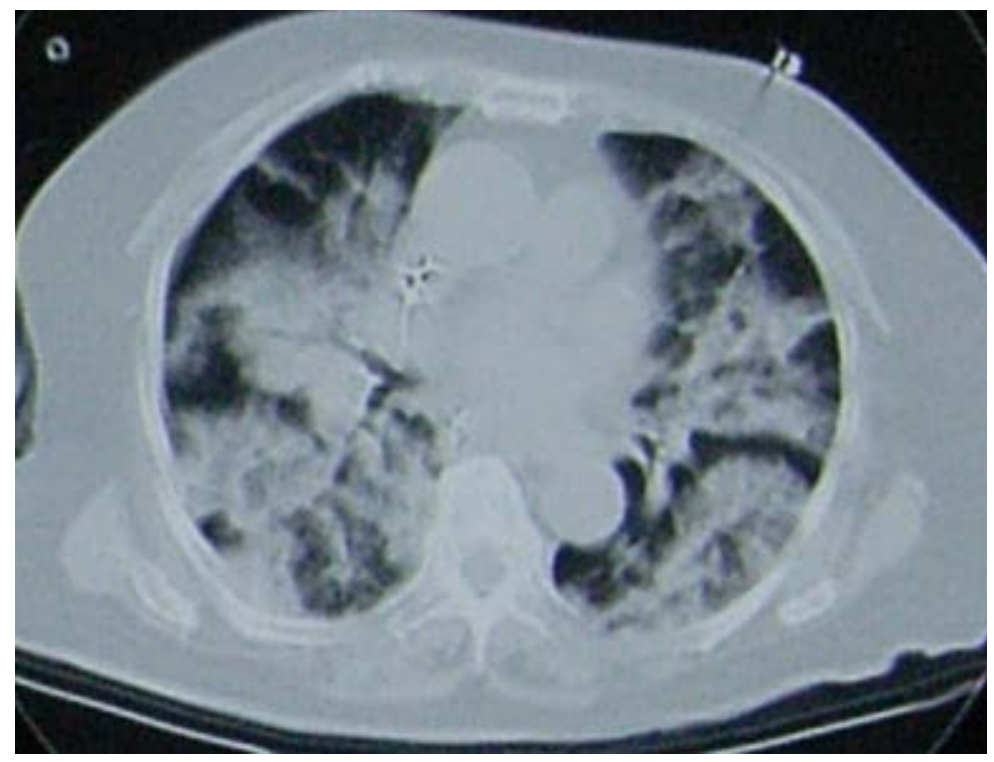

Figure 1. Lung CT of case 1 on admission. There are bilateral pulmonary opacities. 
Table 1. Laboratory data of case 1 on admission.

\begin{tabular}{|c|c|c|c|}
\hline \multicolumn{2}{|c|}{ Hematology } & \multicolumn{2}{|c|}{ Blood chemistry } \\
\hline WBC & $7090 / \mu \mathrm{l}$ & $\mathrm{TP}$ & $5.7 \mathrm{~g} / \mathrm{dl}$ \\
\hline $\mathrm{RBC}$ & $478 \times 10^{4} / \mu \mathrm{l}$ & Alb & $4.9 \mathrm{~g} / \mathrm{dl}$ \\
\hline $\mathrm{Hb}$ & $14.1 \mathrm{~g} / \mathrm{dl}$ & BUN & $34.7 \mathrm{mg} / \mathrm{dl}$ \\
\hline $\mathrm{Ht}$ & $42.30 \%$ & Cre & $1.2 \mathrm{mg} / \mathrm{dl}$ \\
\hline Plt & $19.6 \times 104 / \mu \mathrm{l}$ & $\mathrm{Na}$ & $143 \mathrm{mEq} / \mathrm{l}$ \\
\hline- & - & $\mathrm{K}$ & $5.6 \mathrm{mEq} / \mathrm{l}$ \\
\hline \multicolumn{2}{|c|}{ Arterial blood gas analysis } & $\mathrm{Cl}$ & $114 \mathrm{mFq} / \mathrm{l}$ \\
\hline \multicolumn{2}{|c|}{ ( $\mathrm{O}_{2} 10 \mathrm{~L}$ intubation) } & $\mathrm{Ca}$ & $8.2 \mathrm{mg} / \mathrm{dl}$ \\
\hline $\mathrm{pH}$ & 7.282 & AST & $72 \mathrm{IU} / \mathrm{l}$ \\
\hline $\mathrm{pCO}_{2}$ & $31.1 \mathrm{mmHg}$ & ALT & $49 \mathrm{IU} / \mathrm{l}$ \\
\hline $\mathrm{pO}_{2}$ & $168.4 \mathrm{mmHg}$ & T-Bil & $0.6 \mathrm{mg} / \mathrm{dl}$ \\
\hline $\mathrm{HCO}_{3}$ & $14.3 \mathrm{mmol} / \mathrm{l}$ & Amylase & $1125 \mathrm{IU} / \mathrm{l}$ \\
\hline $\mathrm{BE}$ & $-11.0 \mathrm{mmol} / \mathrm{l}$ & BS & $689 \mathrm{mg} / \mathrm{dl}$ \\
\hline- & - & CRP & $6.1 \mathrm{mg} / \mathrm{dl}$ \\
\hline- & - & CPK & $1688 \mathrm{IU} / \mathrm{l}$ \\
\hline
\end{tabular}

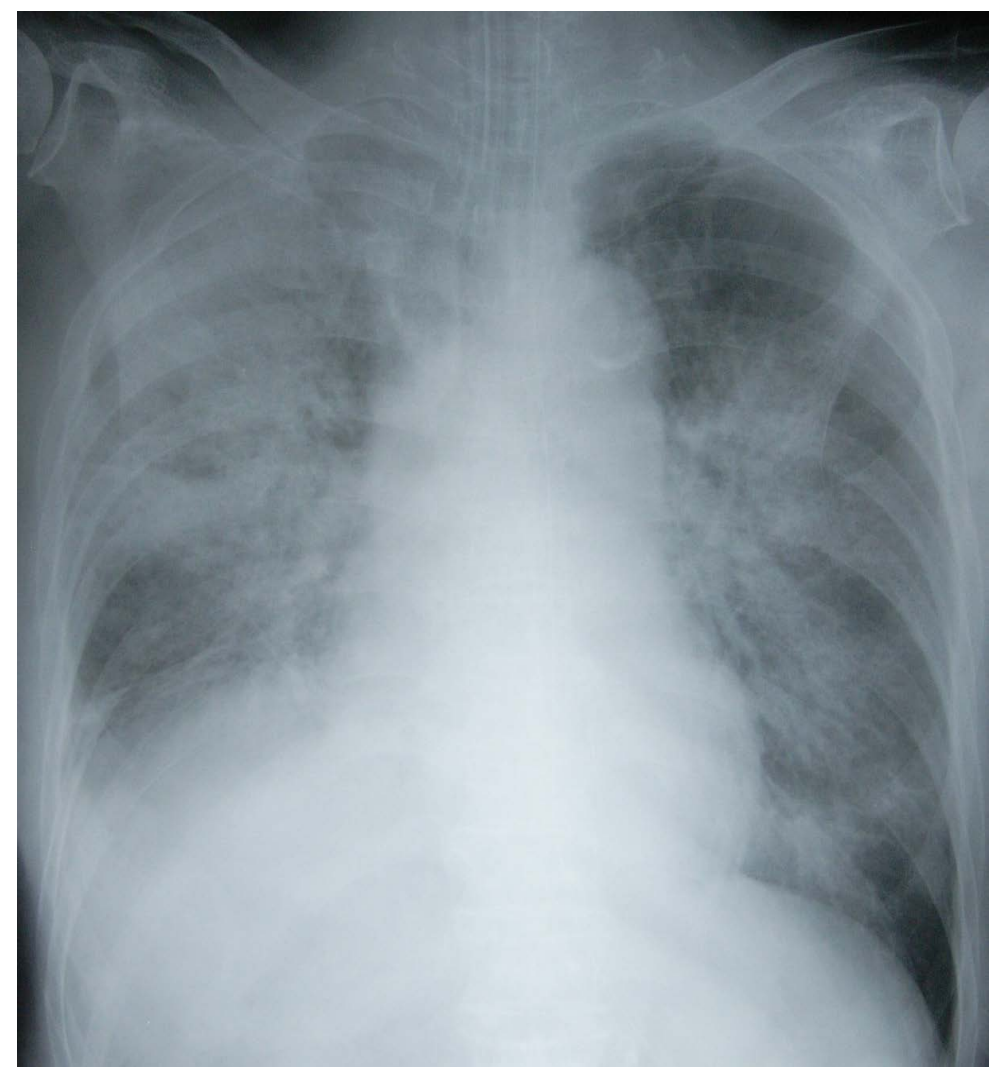

Figure 2. Chest X-ray of case 2 on the next day of admission. There are diffuse bilateral consolidations. 
Table 2. Laboratory data of case 2 on admission.

\begin{tabular}{|c|c|c|c|}
\hline \multicolumn{2}{|c|}{ Hematology } & \multicolumn{2}{|c|}{ Blood chemistry } \\
\hline WBC & $10,730 / \mu \mathrm{l}$ & $\mathrm{TP}$ & $5.6 \mathrm{~g} / \mathrm{dl}$ \\
\hline $\mathrm{RBC}$ & $298 \times 10^{4} / \mu \mathrm{l}$ & Alb & $2.9 \mathrm{~g} / \mathrm{dl}$ \\
\hline $\mathrm{Hb}$ & $10.2 \mathrm{~g} / \mathrm{dl}$ & BUN & $23.5 \mathrm{mg} / \mathrm{dl}$ \\
\hline $\mathrm{Ht}$ & $30.30 \%$ & Cre & $0.8 \mathrm{mg} / \mathrm{dl}$ \\
\hline Plt & $18.4 \times 10^{4} / \mu \mathrm{l}$ & $\mathrm{Na}$ & $143 \mathrm{mEq} / \mathrm{l}$ \\
\hline- & - & $\mathrm{K}$ & $4.2 \mathrm{mEq} / \mathrm{l}$ \\
\hline \multicolumn{2}{|c|}{ Arterial blood gas analysis } & $\mathrm{Cl}$ & $113 \mathrm{mFq} / \mathrm{l}$ \\
\hline \multicolumn{2}{|c|}{ ( $\mathrm{FiO}_{2} 0.6$ intubation) } & $\mathrm{Ca}$ & $8.6 \mathrm{mg} / \mathrm{dl}$ \\
\hline $\mathrm{pH}$ & 7.375 & AST & $31 \mathrm{IU} / \mathrm{l}$ \\
\hline $\mathrm{pCO}_{2}$ & $34.8 \mathrm{mmHg}$ & ALT & $18 \mathrm{IU} / \mathrm{l}$ \\
\hline $\mathrm{pO}_{2}$ & $51.4 \mathrm{mmHg}$ & T-Bil & $0.6 \mathrm{mg} / \mathrm{dl}$ \\
\hline $\mathrm{HCO}_{3}$ & $19.9 \mathrm{mmol} / \mathrm{l}$ & Amylase & $41 \mathrm{IU} / \mathrm{l}$ \\
\hline $\mathrm{BE}$ & $-4.7 \mathrm{mmol} / \mathrm{l}$ & BS & $242 \mathrm{mg} / \mathrm{dl}$ \\
\hline- & - & CRP & $4.2 \mathrm{mg} / \mathrm{dl}$ \\
\hline- & - & CPK & $308 \mathrm{IU} / \mathrm{l}$ \\
\hline
\end{tabular}

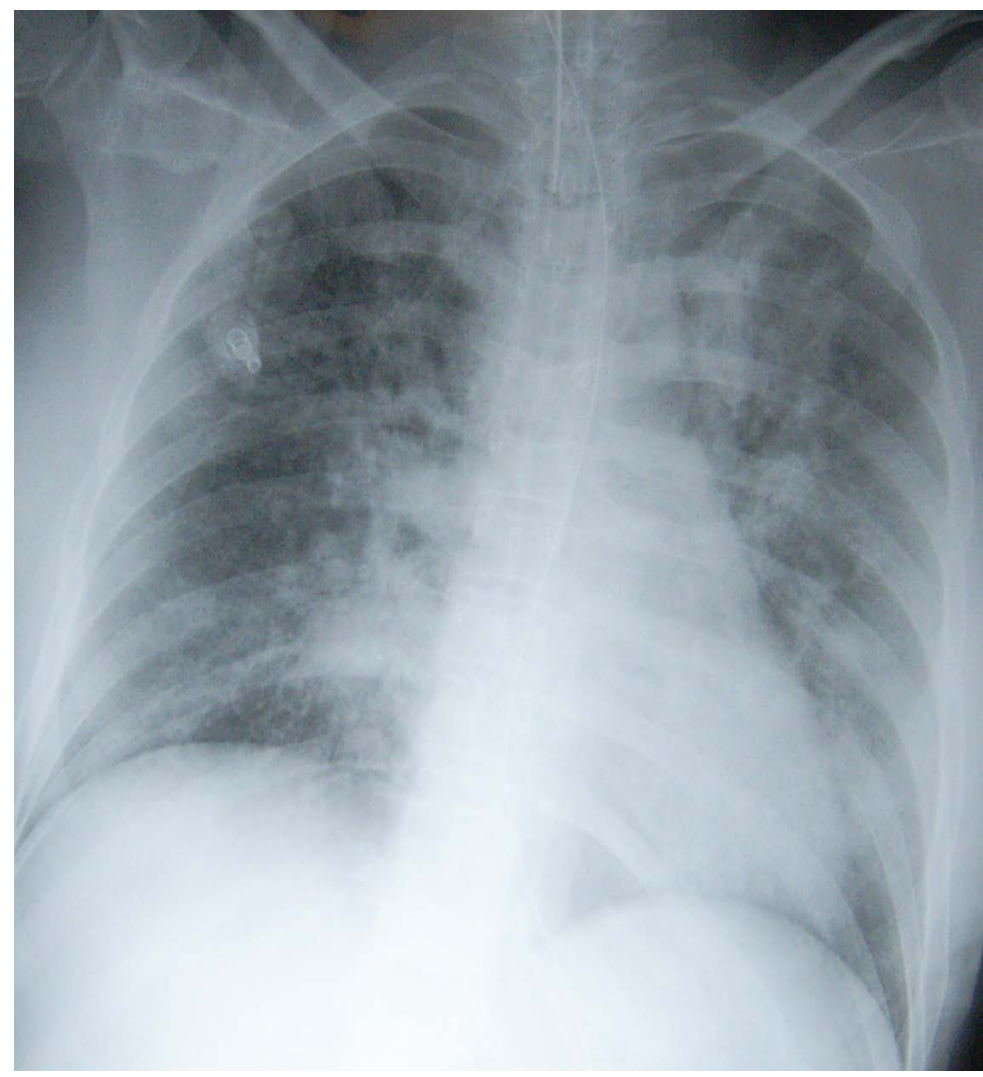

Figure 3. Chest X-ray of case 3 on the next day of admission. There are diffuse bilateral consolidations. 
Table 3. Laboratory data of case 3 on admission.

\begin{tabular}{|c|c|c|c|}
\hline \multicolumn{2}{|c|}{ Hematology } & \multicolumn{2}{|c|}{ Blood chemistry } \\
\hline WBC & $5810 / \mu \mathrm{l}$ & $\mathrm{TP}$ & $5.4 \mathrm{~g} / \mathrm{dl}$ \\
\hline $\mathrm{RBC}$ & $392 \times 10^{4} / \mu \mathrm{l}$ & Alb & $3.2 \mathrm{~g} / \mathrm{dl}$ \\
\hline $\mathrm{Hb}$ & $10.8 \mathrm{~g} / \mathrm{dl}$ & BUN & $12.9 \mathrm{mg} / \mathrm{dl}$ \\
\hline $\mathrm{Ht}$ & $33.60 \%$ & Cre & $0.5 \mathrm{mg} / \mathrm{dl}$ \\
\hline Plt & $18.4 \times 10^{4} / \mu \mathrm{l}$ & $\mathrm{Na}$ & $145 \mathrm{mEq} / \mathrm{l}$ \\
\hline- & - & $\mathrm{K}$ & $3.8 \mathrm{mEq} / \mathrm{l}$ \\
\hline \multicolumn{2}{|c|}{ Arterial blood gas analysis } & $\mathrm{Cl}$ & $112 \mathrm{mFq} / \mathrm{l}$ \\
\hline \multicolumn{2}{|c|}{ ( $\mathrm{O}_{2} 15 \mathrm{~L}$ intubation) } & $\mathrm{Ca}$ & $8.5 \mathrm{mg} / \mathrm{dl}$ \\
\hline $\mathrm{pH}$ & 7.318 & AST & $50 \mathrm{IU} / \mathrm{l}$ \\
\hline $\mathrm{pCO}_{2}$ & $44.7 \mathrm{mmHg}$ & ALT & $33 \mathrm{IU} / \mathrm{l}$ \\
\hline $\mathrm{pO}_{2}$ & $245.7 \mathrm{mmHg}$ & T-Bil & $0.4 \mathrm{mg} / \mathrm{dl}$ \\
\hline $\mathrm{HCO}_{3}$ & $22.5 \mathrm{mmol} / \mathrm{l}$ & Amylase & $320 \mathrm{IU} / \mathrm{l}$ \\
\hline $\mathrm{BE}$ & $-3.6 \mathrm{mmol} / \mathrm{l}$ & BS & $99 \mathrm{mg} / \mathrm{dl}$ \\
\hline- & - & CRP & $13.4 \mathrm{mg} / \mathrm{dl}$ \\
\hline- & - & CPK & $1109 \mathrm{IU} / \mathrm{l}$ \\
\hline
\end{tabular}

\section{Case 3}

A 33-year-old female. Past medical history: None. Delivered her first child in January 2011. She was engulfed by the tsunami that occurred on March 11 and was rescued in a near-drowned state. She was transported to a local general hospital at 9:43 pm, but she was covered with heavy oil. Mechanical ventilation was instituted, but she was diagnosed as severely ill and transported to our center by helicopter at 12:40 pm the following day, March 12. Status praesens: Her consciousness level was 1 (JCS) and E4VTM6 (GCS), and it was even possible to communicate by written messages. Numerous bruises and abrasions were observed on her face, trunk, and both lower limbs. The blood examination findings are shown in Table 3, and the X-p chest X-ray taken in the next day of admission is shown in Figure 3. After treatment in the outpatient department, the patient was admitted to the ICU. Hospital course: She was treated with injection of antibiotics (MEPM) and placed on mechanical ventilation. Initially, a $\mathrm{FiO}_{2} 1.0$ was used, however, her $\mathrm{SpO}_{2}$ was 100 , and the $\mathrm{FiO}_{2}$ was reduced to 0.5 the next day and to 0.4 on March 14 , but a fever of over $38^{\circ} \mathrm{C}$ persisted. Her respiratory status began to deteriorate on March 21, and despite ECMO treatment, it failed to improve, and she died of respiratory dysfunction on March 27. A bacteriological examination of her sputum yielded only normal flora initially, but Stenotrophomonas maltophilia, Legionella pneumophila, Burkholderia cepacia and Pseudomonas aeruginosa was detected on March 22.

\section{Discussion}

The Great East Japan Earthquake is often compared to the Great Hanshin Earthquake that occurred in 1995, but the situations were quite different. Of course, there were differences in the time and place of occurrence and in their scale, but the greatest difference was in the mechanism of the disaster. There were 6434 deaths in the Great Hanshin Earthquake, however, because it occurred when most of victims were asleep in the early hours in midwinter, the cause of approximately $80 \%$ of the deaths was asphyxia or crushing by residences or buildings that had collapsed. By contrast, the cause of most of the deaths in the Great East Japan Earthquake was drowning as a result of engulfment by the giant tsunami that followed. According to the announcement by the National Police Agency on April 19, 13,154 bodies had been recovered during the month to April 11, and 11,026 of them had been identified. The results of the analysis of the 13,135 in which a postmortem examination had been com- 
pleted showed that drowning was the cause of death in 12143, accounting for 92.5\% of the deaths. Examination of the data for Miyagi Prefecture, Iwate Prefecture, and Fukushima Prefecture, the three prefectures with the largest numbers of deaths, revealed that the following percentages of deaths were due to drowning: Miyagi Prefecture, 95.7\%; Iwate Prefecture, 87.3\%; and Fukushima Prefecture, 87.0\%. In addition to the drownings, there were 148 deaths from burns (1.1\%), 578 deaths (4.4\%) from crushing, injuries, and other causes, and 266 (2.0\%) from unknown causes. In Iwate Prefecture 1.6\% of the deaths were from burns, and in Fukushima Prefecture $12.6 \%$ were from crushing, injuries, and other causes. The deaths from burns were due to fires caused by the tsunami, and they were most common in the areas where the fires were the fiercest, such the city of Kesenuma in Miyagi Prefecture and the town of Otsuchi in Iwate Prefecture. In addition, many of the crushing deaths and deaths from injuries appeared to have been due to being pinned under residences that had collapsed as a result of the tsunami and to collisions with debris while drifting. An analysis of the 11,108 remains whose sex and age had been determined showed that 7036 were female and 5971 male, and the most common age group was 70 79 years old (2663, 24.0\%), followed by 80 years old and over (2454, 22.1\%), and 60 - 69 years old (2124, $19.1 \%$ ), with those 60 years old and over accounting for 7241 , or $65.2 \%$.

The near drownings consisted of near drownings caused by freshwater when they occurred in rivers or lakes (or in bathtubs, pools, etc.), and, mostly, of near drownings caused by saltwater when they occurred in seawater, and the differences between them are said to be attributable to the osmotic pressure exerted by the salt in seawater. Recently, however, the prevailing opinion is that large enough volumes of water to cause electrolyte abnormalities in the body seldom enter the lungs, and that the differences between freshwater and saltwater do not have much impact [1] [2]. Nevertheless, near drownings caused by the tsunamis appear to differ even more from simply near drowning in saltwater, and that appears to be because the seawater that sweeps over the land during tsunamis assails people as it engulfs a variety of objects on land (earth and sand, buildings, vehicles, sewage, fats and oils, etc). As a result, the seawater that enters the lungs also contains a variety of substances, and they appear to make the pathology complicated. The substances thought to be mostly involved are fats and oils. Various types of fats and oils cover the surface of seawater as a result of tsunamis: kerosene from homes, gasoline and light oil from motor vehicles and ships, heavy oil from ships and factories, and even petroleum from stockpiles along the coast. When people who are engulfed by a tsunami try to breathe, they try to rise above the surface of the sea (or in terms of specific gravity, they float), and when they do they aspirate the fats and oils on the surface of the water. When fats and oils enter the lungs they induce serious chemical pneumonitis, and the pathology appears to be made even more serious when infectious pneumonia caused by contaminated seawater is added to it. In all three cases described above, the patient was female, and based on the circumstances at the time they were discovered, swallowing of fats or oils was postulated in at least two of them. Aeromonas species and Burkholderia pseudomallei are said to be the most common causative organisms of the bacterial pneumonia that develops as a result of near drowning in fresh water, Francisella philomiragia in seawater, and Pseudallescheria boydii and Pseudomonas aeruginosa in polluted water [3]. There is also a report of saving the lives of patients who nearly drowned as a result of the Okushiri Island tsunami of 1994 [4]. Stenotrophomonas maltophilia, formerly known by the name Xanthomonas maltophilia, was detected in two of the three patients we treated. It is a glucose-non-fermenting gram-negative bacillus that is widely distributed in the natural world, and it is a multiple-drug resistant and multiple-disinfectant resistant bacterium. Moreover, because it produces metallo- $\beta$-lactamase chromosome dependently, it exhibits natural resistance to carbapenems, cephamycins, etc. The antibiotics we used to treat both patients happened to be carbapenems. As a result, it was postulated that worsening of the infection by Stenotrophomonas maltophilia that proliferated as a result of bacterial substitution because the carbapenems had been used was a factor that led to their respiratory status again deteriorating after it had improved following their hospital admission, and to their death.

\section{Conclusion}

We treated three cases of near drowning as a result of a tsunami. Prevention of drowning is only escaping from tsunami. The outcome was fatal in all three cases, but the fact that the rapid helicopter transport based on the lessons learned in the Great Hanshin Earthquake was temporarily successful also should be evaluated. Moreover, we think that we have definitely provided a clue to the selection of antibiotics that may cause infection by replacement bacteria in the treatment of this severe pneumonia. If drowning of tsunami is encountered, we should choose not carbapenem but new quinolone and tetracycline for antibiotic treatment. 


\section{References}

[1] Hitoshi, G. (2011) Near-Drowning. Japanese Journal of Pediatric Medicine, 43, 123-125.

[2] Hitoshi, I. and Yoshiki, M. (2009) Acute Lung Injury in Near-Drowning Victims. Jpn J Clin Med A New Domain Series of Syndrome No 5, Nippon Rinshou Sha Press, Tokyo, 203-209.

[3] Ender, P.T. and Dolan, M.J. (1997) Pneumonia Associated with Near-Drowning. Clinical Infectious Diseases, 25, 896907. http://dx.doi.org/10.1086/515532

[4] Shuusihn, Y., Akinori, K., Takashi, H., Naoko, T. and Izumi, Y. (1994) Four Cases of Near-Drowning in Tsunami. Japanese Journal of ICU\&CCU, 18, 1187-1192. 
Scientific Research Publishing (SCIRP) is one of the largest Open Access journal publishers. It is currently publishing more than 200 open access, online, peer-reviewed journals covering a wide range of academic disciplines. SCIRP serves the worldwide academic communities and contributes to the progress and application of science with its publication.

Other selected journals from SCIRP are listed as below. Submit your manuscript to us via either submit@scirp.org or Online Submission Portal.
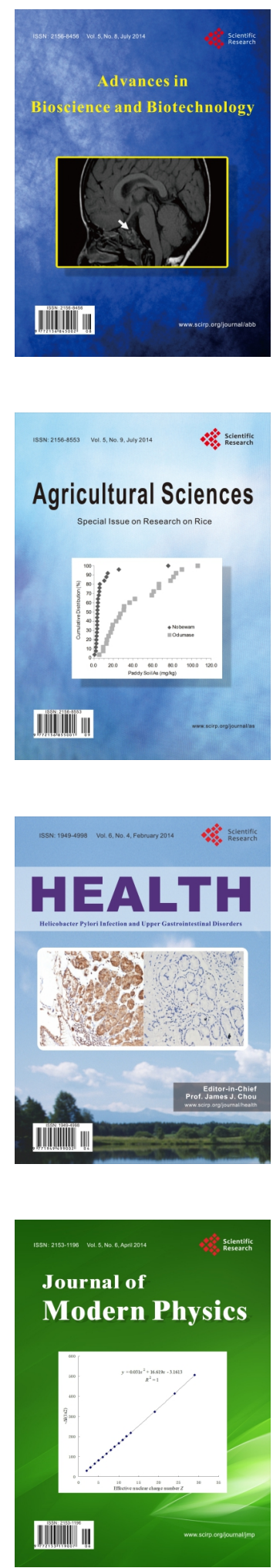
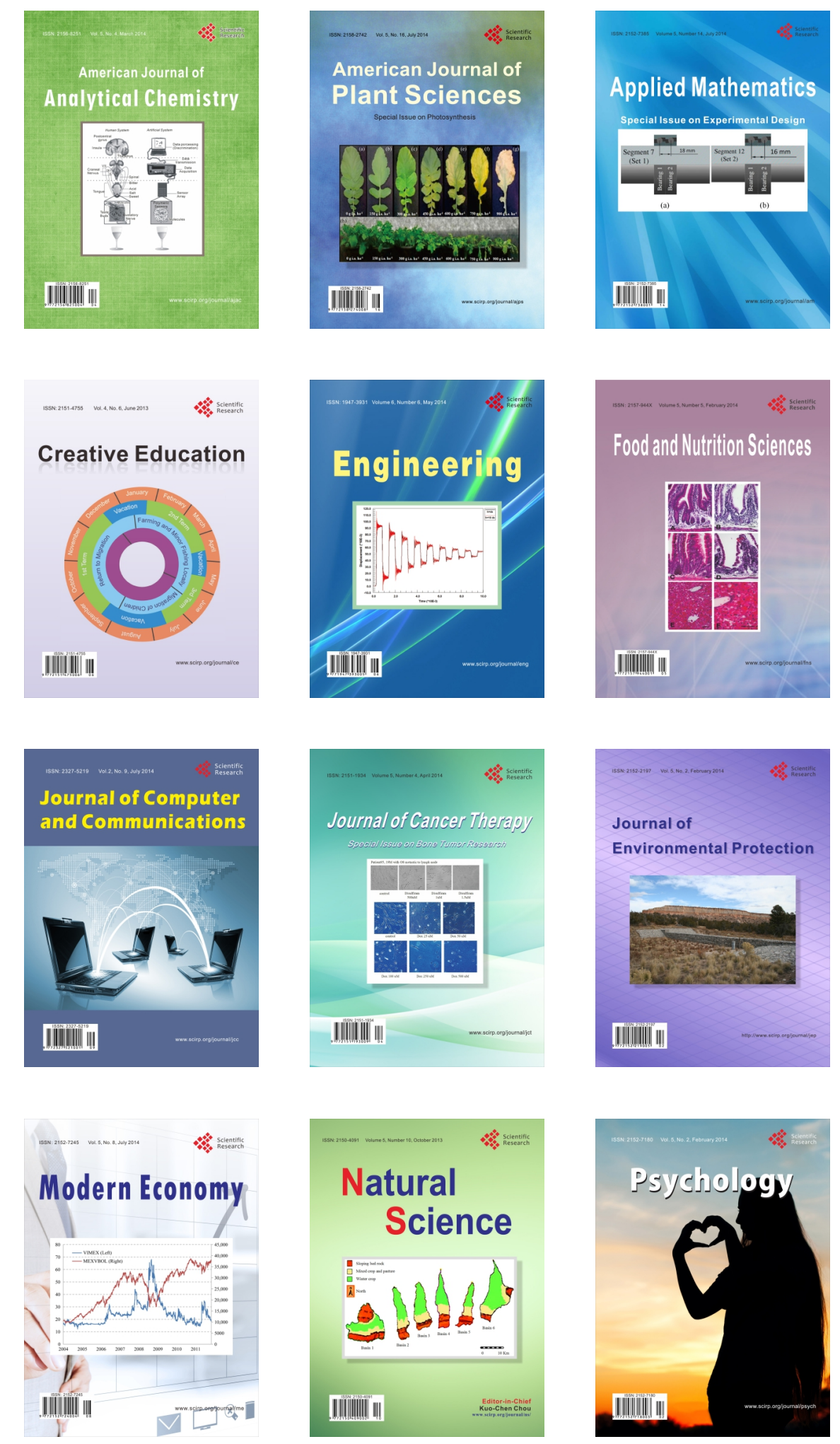